\title{
AZ INFORMÁCIÓS RENDSZEREK KISVÁLLALATI ALKALMAZÁSÁNAK VIZSGÁLATA
}

\section{MAGYAR- ÉS HORVÁTORSZÁGI ÖSSZEHASONLÍTÓ ELEMZÉS}

A szerzố kutatásának célja a magyarországi és a horvátországi vállalkozások információs rendszerek használatának feltárása, az információs rendszer bevezetéséról hozott döntések körülményeinek és használati szokásainak megismerése. Az empirikus felmérés mintájában szerepló horvát vállalkozások nagyobb arányban használják az információs rendszereket. A két ország azonos méretú́ vállalkozásai, a mikrovállalkozások kivételével, hasonló tényezóket mérlegelnek, mielốtt egy információs rendszert bevezetnek ${ }^{1}$.

\section{Kulcsszavak: információs rendszer, kkv, vállalkozói felmérés, Magyarország, Horvátország}

Napjaink gazdaságában felértékelődött az információ mint erőforrás szerepe, ugyanis egyre nehezebben képzelhetô el, hogy az információval való megfelelő fokú ellátottság nélkül a vállalatok képesek hosszú távon is piaci pozíciójuk javítására. Globalizálódó világunkban egyre többféle információhoz juthatunk rövidebb idố alatt, amelynek kezelése is több energiát és idốt igényel a vállalatok részéról. Éppen ezért nem elegendố csupán rendelkezni az információval, annak megfelelô formában való megjelenítése és rendszeres karbantartása is szükséges. Ebben nyújthatnak hatékony segítséget az információs rendszerek, amelyek a technológiai fejlódésnek köszönhetóen egyre elterjedtebbé válnak.

A kutatásom célja a magyarországi és a horvátországi vállalkozások információs rendszerek használatának feltárása, az információs rendszer bevezetéséról hozott döntések körülményeinek és használati szokásainak megismerése.

Az empirikus kutatást megelőzően - a korábbi vizsgálatok eredményére támaszkodva - az alábbi elófeltevések fogalmazódtak meg az országok között lehetséges eltérésekkel és hasonlóságokkal kapcsolatosan:

A magyarországi vállalkozások által használt információs rendszerek elterjedtsége magasabb szintú, mint az európai uniós csatlakozás előtt álló Horvátországé. Ezt a feltételezést az indokolja, hogy Magyarország korábbi európai eniós csatlakozásával megteremtódtek azok a lehetôségek, illetve egyúttal elvárások is, amelyek együttes hatásával az információs rendszerek lehetôségeit a hazai vállalkozások nagyobb mértékben hasznosíthatják.

A különböző országokban, de azonos méretkategóriába tartozó vállalkozások információs-rendszer választási szempontjai hasonlóak. Ebben az esetben a feltételezés alapja, hogy a külsó hatások erős hasonlósága eredményeként a vállalkozások múködésükben is hasonló rendszer-használati szokásokat alkalmaznak.

A kérdőívek kiértékelése után az összefüggések meghatározásával és elemzésével megállapítható, hogy a megfogalmazott feltételezések a kutatás eredményeivel alátámaszthatóak-e.

A teljes kutatás eddig kilenc országban fejezôdött be. A kutatás rövid távú célja a vizsgált országok vállalkozásainál az informatika fejlettségének bemutatása és elemzése. A magyarországi primer kutatást megismételtem és befejeztem Ausztriában, Bosznia-Hercegovinában, Csehországban, Horvátországban, Lengyelországban, Olaszországban és Szlovákiában (1. táblázat). 
A kutatásban részt vevő és befejezô országok, egyetemek és a kutatást irányító személyek

\begin{tabular}{|l|l|l|}
\hline \multicolumn{1}{|c|}{ Ország } & \multicolumn{1}{|c|}{$\begin{array}{c}\text { A helyi kutatást irányító egyetem } \\
\text { neve }\end{array}$} & \multicolumn{1}{c|}{$\begin{array}{c}\text { A helyi kutatást irányító személy } \\
\text { neve }\end{array}$} \\
\hline Ausztria & Karl-Franzens-Universität Graz & Prof. Dr. Wolf Rauch \\
\hline Bosznia-Hercegovina & University of Sarajevo & Amila Pilav-Velić \\
\hline Csehország & Masaryk University, Brno & Ladislav Siska \\
\hline Horvátország & University of Zagreb & Mirjana Pejic Bach, PhD \\
\hline Lengyelország & Maria Curie-Sklodowska University in Lublin & Zbigniew Pastuszak, PhD \\
\hline Magyarország & Miskolci Egyetem & Sasvári Péter, PhD \\
\hline Olaszország & Università degli Studi di Urbino „Carlo Bo” & Prof. Massimo Ciambotti \\
\hline Portugália & Universidade Portucalense, Porto & Maria Filomena Cerqueira Castro Lopes \\
\hline Szlovákia & Miskolci Egyetem & Sasvári Péter, PhD \\
\hline
\end{tabular}

A kutatáshoz újonnan kapcsolódó országok, egyetemek és a kutatást irányító személyek

\begin{tabular}{|l|l|l|}
\hline \multicolumn{1}{|c|}{ Ország } & A helyi kutatást irányító egyetem neve & A helyi kutatást irányító személy neve \\
\hline EURÓPA & & \\
\hline Egyesült Királyság & Edge Hill University & Gillian Rawlings \\
\hline Fehéroroszország & Belarus Trade Economic University, Gomel & Prof. Andrei N. Semeniuta \\
\hline Lettország & Daugavpils Universitātes & Dr. Vera Boronenko \\
\hline Oroszország & Belgorod State University & Prof. Lomakin Vladimir \\
\hline Spanyolország & Public University of Navarra & Fernando Lera \\
\hline AMERIKA & & \\
\hline Argentína & Universidad de San Pablo-T, Tucumàn & Dr. Juan Pablo Lichtmajer \\
\hline Brazília & Universidade Federal dos Vales do & Georgia Fernandes Barros \\
\hline Egyesült Államok & Jequitinhonha e Mucuri & Dr. Nancy Church \\
\hline ÁZSIA & & \\
\hline Koreai Köztársaság & Seoul National University from South Korea & Prof. Dr. Jörn Altmann \\
\hline Malajzia & Multimedia University & Dr. Khong-Sin Tan \\
\hline Szaúd-Arábia & Alfaisal University & Dr Hazbo Skoko \\
\hline AFRIKA & & \\
\hline Dél-Afrika & Durban University of Technology & Delene Heukelman \\
\hline
\end{tabular}

A kérdőívek kitöltésében és fordításában az 1. táblázatban felsorolt egyetemek oktatói segítettek.

A kutatás hosszú távú célja a mintavételezés kiterjesztése további európai, amerikai, ázsiai és afrikai országokra (2. táblázat).

További cél az így kapott adatok alapján összehasonlító elemzések készítése, illetve kutatási hálózat kiépítése a felsorolt egyetemekkel és országokkal.

\section{Az információs rendszer fogalma, csoportosítása és bevezetése}

Az információs rendszer fogalmának meghatározására a szakirodalom többféle definíciót is felkínál. Burt (2012) szerint ,az információs rendszer úgy tekinthetô, mint információforrás(ok) bármilyen kombinációban, azok bármilyen elérésével és/vagy bármilyen visszanyerésével, azok manipulálására vagy használatára. 
Bármilyen információs rendszer célja összekapcsolni a felhasználót egy olyan megfeleló információforrással, melyre a felhasználónak ténylegesen szüksége van, azzal az elvárással, hogy a felhasználó képes lesz elérni az információt, mely meg fog felelni az igényeinek."

Csala és munkatársai (Csala - Csetényi - Tarlós, 2003) definíciója szerint az ,informatikai rendszerek olyan rendszerek, amelyek egy szervezet különféle (üzleti, vállalati) folyamataiban az információs technológia felhasználásával gyújtenek információkat, közvetítik, tárolják, visszakeresik, feldolgozzák, átalakítják és megjelenítik azokat."

Raffai (2003) a következóket érti az információrendszer fogalma alatt: ,a különböző feldolgozásokhoz alapvetố erőforrásként adatokat, információkat használ fel annak érdekében, hogy a szervezeti feladatok végzéséhez hasznos információkat szolgáltasson. Fó célja tehát az információ elóállítása, vagyis olyan célorientált üzenetek létrehozása, amelyek a felhasználo számára újdonságot jelentenek, bizonytalanságot szüntetnek meg, és feladataik, döntéseik teljesítésében segítséget nyújtanak."

\section{Az információs rendszerek csoportosítási lehetôségei}

$\mathrm{Az}$ információs rendszerek csoportosítása nehéz feladat, ugyanis a folyamatos fejlódés miatt nehéz olyan csoportosítási rendszert találni, amelyben egységesen, pontosan lehatárolva jelennek meg a különbözó típusok. Elófordul, hogy ugyanarra a rendszerre az egyes csoportosítási módok más-más rövidítést alkalmaznak, vagy egyes típusok összevontan jelennek meg. Az információs rendszerek osztályozását több szempontból is elvégeztem, a teljesség igénye nélkül néhányat az alábbiakban mutatok be.

A szakirodalom (Dobay, 1997: p. 34-35.) a következố típusokat különbözteti meg: irodaautomatizálási rendszerek (OAS), kommunikációs rendszerek, tranzakció-feldolgozási rendszerek (TPS), menedzsment információs rendszerek (MIR, MIS), vezetôi információs rendszerek (VIR, EIS), döntéstámogató rendszerek (DSS), végrehajtási információs rendszerek (,üzemirányítás”, termelésmenedzsment), csoportmunka-rendszerek.

Egy másik megközelítésben (Raffai, 2003: p. 111.) az alábbi kategóriákat állíthatjuk fel: végrehajtást, vezetôi munkát és egyéb feladatokat támogató rendszerek.

Végül következzen egy olyan osztályozási rendszer (Kacsukné Bruckner - Kiss, 2007: p. 122-123.), amely az e cikkben ismertetett primer kutatás elkészítéséhez is elvi segítséget adott:

- TPS - tranzakció-feldolgozó rendszer (Transaction Processing System): A napi üzletmenettel kapcsola- tos adatok gyứjtésére és tárolására, illetve magasabb szintủ rendszerek adatbázisául szolgál, mindennapos üzleti események lebonyolítását felügyeli.

- MIS - vezetói információs rendszer (Management Information System): Előre definiált jelentéseket készít rendszeres idóközönként, igény szerint vagy különleges események bekövetkezésekor, amely során a menedzserek információigényére összpontosít és jól meghatározott, strukturált problémák megoldásához nyújt segítséget.

- DSS - döntéstámogató rendszer (Decision Support System): A MIS természetes továbbfejlesztése, egy adott problémára koncentrál. Interaktivitást, ad hoc lekérdezést tesz lehetővé.

- EIS - felsôvezetói információs rendszer (Executive Information System): A legfelsố vezetôi réteg igényeit elégíti ki, mivel összegzett, grafikus, a legfontosabb tényezókre koncentráló információt nyújt, de lehetôség van a részletek megtekintésére is.

- ERP - vállalati eróforrás-tervezố rendszer (Enterprise Resource Planning): Feladata a termelés és a hozzá kapcsolódó erőforrások integrált tervezése (pénzügyi, humán stb.), de tartalmazhatja a vevô- és szállítókapcsolatok, valamint az ellátási lánc menedzselését is.

- CRM - ügyfélkapcsolat-kezeló rendszer (Customer Relationship Management): Ügyfelekkel kapcsolatos keresztfunkcionális rendszer, operatív szinten segíti a marketing- és ügyfélszolgálati munkát, valamint taktikai (esetleg stratégiai) szinten segíti a termékfejlesztést és a marketingstratégiák kialakítását.

- SRM - beszállítóikapcsolat-kezelő rendszer (Supplier Relationship Management): Beszállítókkal és a beszerzésekkel kapcsolatos keresztfunkcionális rendszer, fóként operatív és taktikai szinten nyújt támogatást a döntésekhez.

- SCM - ellátási lánc-kezelố rendszer (Supply Chain Management): Segíti a vevô-beszállító kapcsolatban álló vállalatok közötti együttmúködést, célja a teljes ellátási lánc hatékonyságának növelése. Fóként operatív és taktikai szinten nyújt támogatást a döntésekhez.

- BI - üzleti intelligencia-rendszer (Business Intelli-gence): Információforrásként adattárházat használ tisztított és elôfeldolgozott adatokkal. Adatbányászati eljárásokat tartalmaz, valamint on-line elemzések elkészítésére is alkalmas (OLAP - Online Analytical Processing).

- EPM - vállalati teljesítménymenedzsment-rendszer (Enterprise Performance Management): Feladata a teljesítményjelzô mutatók számítása, figyelése, a mutatószámok hierarchiajának kezelése.

- KM - tudásmenedzsment-rendszer (Knowledge Management): Gyújtốnév a vállalati tudás összegyưjitésének és szétosztásának eszközeire. 
- ES - szakértố rendszerek (Expert System): Speciális, szúk szakterületen hoz döntést vagy javasol megoldást nem strukturált problémák megoldására, magas szakmai felkészültségứ szakértố tudásának formalizált használatával. Tulajdonképpen tényeket és szabályokat tárol, és ezek alapján következtetéseket von le.

\section{Az információs rendszerek bevezetése}

Mielőtt egy vállalat egy információs rendszer bevezetése mellett dönt, optimális esetben számos tényezốt mérlegel. E folyamat során fontos lépés, hogy kiválasszák a legfontosabb szempontokat, amelyeket aztán a megfeleló súlyokkal ellátva döntenek a legkedvezôbb ajánlat mellett. Lényeges szempontok (Kacsukné Bruckner - Kiss, 2007: p. 253-257.) lehetnek: a gyártó hírneve, a biztonság, a dokumentáció rendelkezésre állása, az ergonómia, a garancia, a használhatóság, a hálózati kapcsolódás, a kipróbálási lehetőség, a kompatibilitás, a költségek, a megbízhatóság, a modularitás, a bővíthetôség, a rugalmasság, a testre szabhatóság (Erdős, 2005: p. 3.), segítségnyújtás a felhasználo számára, szerviz és támogatás, a teljesítmény, a technológia, az új programverziók elérhetốsége.

\section{A Digitális Menetrend}

$\mathrm{Az}$ Európai Unió stratégiai fontosságúnak tartja az információs társadalom által támasztott kihívásoknak való megfelelést, ezért megalkotásra került a Digitális Menetrend (Digital Agenda). Az Európai Bizottság által bemutatott Digitális Menetrend az Európai Unió növekedésére vonatkozóan 2020-ig szóló célkitúzéseket meghatározó Európa 2020 stratégia hét pillérének egyike. Célja, hogy az innováció, a gazdasági növekedés és a haladás előmozdítása érdekében jobban kiaknázza az információs és kommunikációs technológiákban (IKT-k) rejló lehetôségeket. A menetrend az i2010, eEurópa 2005, eEurópa 2002 és az eEurópa nevú kezdeményezéseket követi.

A Digitális Menetrend általánosságban olyan XXI. századi technológiákra és internetes szolgáltatásokra összpontosít, melyek teret adnak az európai szintü munkahelyteremtésnek, a gazdasági növekedésnek, és egyúttal javítanak az európaiak, valamint a vállalkozások mindennapi körülményein. A stratégia az alábbi fontos tényezók javítását túzi ki célul: az egységes digitális piac létrehozása, a digitális rendszerek összehangolása, az internetbe vetett bizalom megalapozása és az on-line biztonság megteremtése, sokkal gyorsabb internet, a kutatási és fejlesztési beruházások bővítése az információs és kommunikációs technológiák (IKT) területén, a digitális ismeretek elterjesztése, az IKT alkalmazása olyan társadalmi kihívások megoldására, mint például az éghajlatváltozás vagy a népesség elöregedése.

\section{A horvát gazdasági jellemzók}

Horvátország az egykori Jugoszlávia hat tagköztársaságának gazdaságilag legjobban fejlett régiói közé tartozott. Az utóbbi évek gazdasági válságának negatív hatásai jelentósen rontották az ország gazdasági mutatóit (GDP, munkanélküliség, az ipari termelési volumen változása). Jelenleg a gazdaság vezető ágazata a szolgáltatás, $s$ ezen belül is az idegenforgalom és a közlekedés. A GDP részarányát tekintve a szolgáltatás $61,6 \%$, az ipar $30,1 \%$ és a mezógazdaság $8,3 \%$.

Horvátország információtechnológiai fejlettségéról elmondható, hogy az internetpenetráció $59,2 \%$-os, az egyik legmagasabb a balkáni régióban, az európai uniós átlagtól azonban elmarad. A küszöbön álló uniós csatlakozás azonban felgyorsította a kommunikációs szektor liberalizációját, ezért a verseny kiélezódésével jelentôs növekedés várható az internethasználók számában. Horvátországban elsősorban az ADSL-alapú internetszolgáltatás terjedt el, hozzájárult ehhez a vezetékes telefonvonalak gyors kiépítése. A mobil szélessávú internet lehetôségét három szolgáltató is biztosítja, a GSM-lefedettség országosan jó, a szélessávhoz szükséges EDGE, UMTS hálózati lefedettség azonban csak a nagyobb városokra és a tengerparti területekre korlátozódik.

$\mathrm{Az}$ ország információtechnológiai fejlettségét meghatározó tényezók alakulását az elmúlt években mutatja a 3. táblázat, amely a magyar adatokat is tartalmazza a könnyebb összehasonlíthatóság érdekében.

3. táblázat

A két ország IKT-mutatói

\begin{tabular}{|l|l|c|c|c|c|c|}
\hline \multicolumn{1}{|c|}{ Megnevezés } & Ország & $\mathbf{2 0 0 6}$ & $\mathbf{2 0 0 7}$ & $\mathbf{2 0 0 8}$ & $\mathbf{2 0 0 9}$ & $\mathbf{2 0 1 0}$ \\
\hline A vezetékeś telefon-fôvonalak száma \\
(ezer lakosra) & Horvátország & 413 & 417 & 425 & 421 & 424 \\
\hline Mobiltelefonok száma & Magyarország & 334 & 324 & 309 & 307 & 298 \\
(ezer lakosra) & Horvátország & 965 & 1137 & 1330 & 1367 & 1445 \\
\hline Szélessávú vezetékes internet-elófizetések száma & Magyarország & 990 & 1100 & 1220 & 1180 & 1203 \\
(ezer lakosra) & Horvátország & 57 & 87 & 119 & 155 & 183 \\
\hline
\end{tabular}

Forrás: Eurostat, European Commission, 2012 


\section{A magyar gazdasági jellemzók}

A magyar gazdaságban, a horváthoz hasonlóan, egyre erősebb a szolgáltató szektor szerepe. A GDP megoszlása alapján: szolgáltatás $64,4 \%$, ipar $30,9 \%$ és mezógazdaság 4,7\%. A magyar gazdaság fejlődése szempontjából kimagasló jelentóségú a döntő́en multinacionális tulajdonú cégek által végzett feldolgozóipari tevékenység, gépgyártás, autógyártás és elektronikai cikkek gyártása. Néhány ilyen vállalkozás termeli meg az exportra kerülő termékek több mint felét.

Magyarországon az internetpenetráció $65,3 \%$. Az internet-előfizetés típusai között jelentős a kábeles előfizetések száma, hazánkban megelózi az ADSL szolgáltatást igénybe vevő́két. A mobilinternet térhódítása volt megfigyelhetô az elmúlt években, a növekedési üteme messze meghaladta a kábeles vagy ADSL-alapú eló- ország más-más fejlődési pályát bejárt kulturális, társadalmi, technológiai és gazdasági környezetbe ágyazott vállalkozásait vizsgálva és összehasonlítva lehetôség nyílik az információsrendszer-használati szokásokban kialakult különbözőségek és azonosságok megállapítására. A nemzetközi összehasonlítás lehetóséget teremt a gazdasági döntéshozók számára a fejlesztendố területek és irányok kijelölésére. A kutatási tevékenység folytatása, rendszeres idóközönkénti ismétlése, a kitúzött célok teljesülésének ellenôrzését, a változó környezeti hatások tendenciáját képes feltárni. Folyamatos monitoringgal támogatva a vállalati és gazdasági élet szereplőinek eredményesebb múködését, hatékonyságuk növelését, információs rendszerekkel kapcsolatos döntéseik objektív megalapozását. A kutatási célokat foglalja össze az 4. táblázatban látható modell.

4. táblázat

A kutatáslogikai modellje

\begin{tabular}{|c|c|c|}
\hline $\begin{array}{l}\text { 1. Az üzleti információs rendszer } \\
\text { bevezetésének körülményei }\end{array}$ & $\begin{array}{l}\text { 2. Üzleti információs } \\
\text { rendszer használati szokások }\end{array}$ & $\begin{array}{l}\text { 3. Az üzleti információs rendszer alkalma- } \\
\text { zásával kapcsolatos elvárások, a rendszer } \\
\text { hatásai a vállalati eredményességre }\end{array}$ \\
\hline $\begin{array}{l}\text { - az informatikai infrastruktúra és az } \\
\text { információs rendszerek helyzete } \\
\text { - bevezetés okai } \\
\text { - megfeleló információs rendszer } \\
\text { kiválasztását béfolyásoló szempontok } \\
\text { - döntést megelózó kalkulációk } \\
\text { - bevezetés során felmerüló problémák }\end{array}$ & $\begin{array}{l}\text { - internethasználat és az interneten } \\
\text { való megjelenés } \\
\text { - az alkalmazott információs rend- } \\
\text { szer típusa és fajtája }\end{array}$ & $\begin{array}{l}\text { - az internet és az üzleti információs } \\
\text { rendszerek használatából származó } \\
\text { elônyök } \\
\text { - a gazdasági-gazdaságossági elemzések } \\
\text { támogatása. }\end{array}$ \\
\hline
\end{tabular}

fizetésekét. Az internetszolgáltatások árbevételét vizsgálva is megállapítható, hogy az ADSL-szolgáltatások részaránya folyamatosan csökken, a kábeles kismértékben nó. A használat szempontjából nézve az internetszolgáltatások típusait az xDSL (új típusú DSL) szolgáltatás a legelterjedtebb, az internetkapcsolattal rendelkezó vállalkozások $68,3 \%$-a használja, de ezen a területen is jelentôs a mobilinternet térhódítása.

\section{A kutatási koncepció ismertetése}

A teljes kutatás a vállalkozások üzleti információsrendszer-használati szokásait igyekszik feltárni. A vizsgálat kiterjed a rendszerek bevezetésének szükségszerúségeire és problémáira, a használat során várható eredményekre és kihívásokra, továbbá a rendszerek használatával elérhetô gazdasági elônyökre. A vállalatok múködésében szinte minden esetben jelentôs mérföldkô egy új rendszer bevezetése, jellemzôen a magas költségek és kockázatok miatt. Az elérhetó előnyök pedig sok esetben nehezen számszerúsíthetớk. A vállalati versenyképességre és azon túl az eredményességre gyakorolt hatásuk csak a komplex vállalati folyamatok egészének vizsgálatával mutatható ki. A két
Az empirikus kutatás egy kérdóíves megkérdezésre épült. A kérdôívek véletlenszerú kiküldése a vállalatok számára méret, tevékenységi terület és regionális elhelyezkedéstól függetlenül történt. A kitöltésüket az EvaSys rendszer alkalmazása segítette az on-line és a papír alapú felmérés párhuzamos biztosításával. Az elemzés megkezdéséig 94 magyar és 80 horvát vállalkozás küldött vissza értékelhetô kérdôívet. A horvát vállalkozások méret szerinti csoportosítása szempontjából a mintában felülreprezentáltak a nagyvállalkozások $(29,8 \%)$, a középvállalkozások $(27,2 \%)$, a kisvállalkozások $(28,5 \%)$, a mikrovállalkozások pedig alulreprezentáltak (14,2\%). A magyar vállalkozások esetében a nagyvállalatok $(21,2 \%)$, a kis- $(28,7 \%)$, illetve a középvállalkozások $(28,7 \%)$ irányába tolódik el a minta. A mikrovállalkozások aránya $21,3 \%$ volt.

\section{Információs rendszerek bevezetésének vizsgálata}

A vállalatok által használt információs rendszerek alkalmazásával kapcsolatban először azt vizsgáltam, hogy használ-e jelenleg az adott vállalkozás valamilyen információs rendszert. A mintában szerepló 
horvát vállalkozások $92 \%$-a használ valamilyen információs rendszert, csak a mikrovállalkozási szinten található öt olyan vállalkozás, amely nem. A magyar vállalkozások 89\%-a alkalmaz ilyen rendszereket. Az információs rendszert nem használó magyar vállalkozások jellemzóen mikrovállalkozások (55\%), továbbá kisvállalkozások (27\%) és középvállalkozások (18\%). Minden mintában szerepló magyar nagyvállalat használ valamilyen információs rendszert. A vállalkozási méret szerint vizsgálva a mikrovállalkozások $30 \%$-a, a kisvállalkozások $11 \%$-a és a közepes vállalkozások 7\%-a pedig nem alkalmaz információs rendszert.

\section{A bevezetésre kerülő́ rendszer kiválasztásának szempontjai}

A kérdőív 20 szempontot sorolt fel, amelyeket öt fokozatú Likert-skálán értékelhettek a vállalatok, attól függóen, hogy az adott szempont egyáltalán nem fontos vagy nagyon fontos számukra a bevezetési döntés során.

A horvát vállalkozások esetében átlagosan a legfontosabb szempontok a hálózati kapcsolódás lehetôsége, a költségek és a használhatóság szempontjai voltak, mind- három tényezô esetében 4,5 vagy magasabb értékkel. A legkevésbé fontos szempontok a kipróbálási lehetôség és az ergonómia volt, 3 és 3,5 átlagos értékkel. A vállalkozási méret szerint vizsgálva a szempontok fontosságát jelentős eltérések mutatkoznak. Megállapítható, hogy a mikrovállalkozások több tényezố esetében jelentốsen eltéró fontosságúnak értékelik az egyes tényezóket, mint a nagyobb vállalkozások A mikrovállalkozások esetében a hálózatkapcsolódás döntố jelentôségú volt, de ez elmondható a többi vállalkozási mérettípus válaszaira is. A kipróbálási lehetôség, mint a rendszer kiválasztása során megjelenő szempont, a mikrovállalkozások esetében jóval fontosabb, mint más vállalkozásoknál, ahol a legkevésbé figyelembe vett tényezó. A rendszer teljesítményét azonban már kevésbé fontosnak értékelik, mint a nagyobb méretkategóriák képviselôi. Jelentősnek mondható az eltérés a költségek fontosságában is, a mikrovállalkozások 3,6-ra értékelik, a többi méretkategória, viszonylag egységesen, átlagosan 4,6 értékre. Meglepó ez a mikrovállalkozások esetében, hiszen az anyagi lehetóségek általában az esetuikben a legkorlátozottabbak (5. táblázat).

\section{Az információs rendszer kiválasztásának szempontjai}

5. táblázat a horvát vállalkozások esetében

\begin{tabular}{|c|c|c|c|c|c|c|c|}
\hline Sorrend & Megnevezés & $\begin{array}{c}\text { Mikro- } \\
\text { vállalkozás } \\
\end{array}$ & $\begin{array}{c}\text { Kis- } \\
\text { vállalkozás } \\
\end{array}$ & $\begin{array}{c}\text { Közép- } \\
\text { vállalkozás }\end{array}$ & $\begin{array}{l}\text { Nagy: } \\
\text { vállalat }\end{array}$ & Átlag & $\begin{array}{c}\begin{array}{c}\text { Magyarországi } \\
\text { sorrend }\end{array} \\
\end{array}$ \\
\hline 1. & Hálózati kapcsolódás & 4,67 & 4,72 & 4,80 & 4,67 & 4,72 & 3. \\
\hline 2. & Költségek & 3,88 & 4,50 & 4,72 & 4,67 & 4,54 & 8. \\
\hline 3. & Használhatóság & 3,38 & 4,56 & 4,47 & $4, \overline{76}$ & 4,45 & 1. \\
\hline 4. & Biztonság & 4,33 & 4,50 & 4,74 & 4,10 & 4,42 & 5. \\
\hline 5. & Szerviz és támogatás & 4,33 & 4,17 & 4,53 & 4,52 & 4,41 & 9. \\
\hline 6. & $\begin{array}{l}\text { Felhasználók támogatása } \\
\text { a bevezetés idószakában }\end{array}$ & 4,83 & 4,22 & 4,26 & 4,40 & 4,35 & 12. \\
\hline 7. & Rugalmasság, testre szabhatóság & 4,17 & 4,33 & 4,42 & 4,24 & 4,31 & 7. \\
\hline 8. & $\begin{array}{l}\text { Felhasználók támogatása } \\
\text { a bevezetés után }\end{array}$ & 4,33 & 4,11 & 4,26 & 4,38 & 4,27 & 16. \\
\hline 9. & Kompatibilitás & 3,50 & 4,17 & 4,32 & 4,43 & 4,21 & 4. \\
\hline 10. & Teljesítmény & 3,63 & 4,11 & 4,26 & 4,38 & 4,18 & 6. \\
\hline 11. & Megbízhatóság & 4,50 & 4,11 & 4,10 & 4,19 & 4,18 & 2. \\
\hline 12. & Modularitás & 3,67 & 3,94 & 4,40 & 4,24 & 4,15 & 10. \\
\hline 13. & $\begin{array}{l}\text { Informatikai stratégiának val6 } \\
\text { megfelelés }\end{array}$ & 4,17 & 3,94 & 4,42 & 4,05 & 4,14 & 13. \\
\hline 14. & Új programverziók elérhetôsége & 4,00 & 3,89 & 4,21 & 4,00 & 4,03 & 14. \\
\hline 15. & Technológia & 3,83 & 3,67 & 4,15 & 4,00 & 3,94 & 15. \\
\hline 16. & A gyártó hírneve & 3,67 & 3,72 & 4,16 & 3,95 & 3,92 & 20. \\
\hline 17. & Garancia & 3,67 & 3,71 & 4,16 & 3,71 & 3,84 & 11. \\
\hline 18. & Dokumentáció rendelkezésre állása & 3,83 & 3,56 & 4,05 & 3,57 & 3,73 & 18. \\
\hline 19. & Ergonómia & 3,50 & 3,61 & 3,79 & 3,52 & 3,63 & 19. \\
\hline 20. & Kipróbálási lehetốség & 3,83 & 3,11 & 3,21 & 2,67 & 3,06 & 17. \\
\hline
\end{tabular}


Az információs rendszer kiválasztásának szempontjai a magyar vállalkozások esetében

\begin{tabular}{|c|c|c|c|c|c|c|c|}
\hline Sorrend & Megnevezés & $\begin{array}{c}\text { Mikro- } \\
\text { vállalkozás }\end{array}$ & $\begin{array}{c}\text { Kis- } \\
\text { vállalkozás } \\
\end{array}$ & $\begin{array}{l}\text { Közép- } \\
\text { vállalkozás }\end{array}$ & $\begin{array}{l}\text { Nagy- } \\
\text { vállalat }\end{array}$ & Átlag & $\begin{array}{c}\text { Horvátországi } \\
\text { sorrend }\end{array}$ \\
\hline 1. & Használhatóság & 5,00 & 4,46 & 4,60 & 4,83 & 4,69 & 3. \\
\hline 2. & Megbízhatóság & 4,13 & 4,46 & 4,60 & 4,56 & 4,50 & 12. \\
\hline 3. & Hálózati kapcsolódás & 4,38 & 4,23 & 4,50 & 4,67 & 4,48 & 1. \\
\hline 4. & Kompatibilitás & 3,75 & 4,54 & 4,38 & 4,56 & 4,38 & 9. \\
\hline 5. & Biztonság & 4,38 & 4,31 & 4,40 & 4,39 & 4,38 & 4. \\
\hline 6. & Teljesítmény & 3,88 & 4,38 & 4,32 & 4,28 & 4,27 & 10. \\
\hline 7. & Rugalmasság, testre szabhatóság & 4,38 & 4,15 & 4,28 & 4,17 & 4,23 & 7. \\
\hline 8. & Költségek & 4,63 & 4,23 & 4,12 & 4,17 & 4,22 & 2. \\
\hline 9. & Szerviz és támogatás & 3,75 & 3,92 & 4,40 & 4,33 & 4,20 & 5. \\
\hline 10. & Modularitás & 4,13 & 4,08 & 4,04 & 4,50 & 4,19 & 12. \\
\hline 11. & Garancia & 3,63 & 3,69 & 4,20 & 4,22 & 4,03 & 17. \\
\hline 12. & $\begin{array}{l}\text { Felhasználók támogatása a } \\
\text { bevezetés idôszakában }\end{array}$ & 2,88 & 4,08 & 4,16 & 4,06 & 3,95 & 6. \\
\hline 13. & $\begin{array}{l}\text { Informatikai stratégiának való } \\
\text { megfelelés }\end{array}$ & 3,63 & 3,77 & 4,04 & 3,94 & 3,91 & 13. \\
\hline 14. & Új programverziók elérhetơsége & 3,50 & 3,92 & 3,92 & 4,00 & 3,89 & 14. \\
\hline 15. & Technologia & 3,25 & 3,62 & 4,00 & 4,17 & 3,87 & 15. \\
\hline 16. & $\begin{array}{l}\text { Felhasználók támogatása a } \\
\text { bevezetés után }\end{array}$ & 2,86 & 3,67 & 4,04 & 4,00 & 3,82 & 8. \\
\hline 17. & Kipróbálási lehetốség & 4,38 & 3,85 & 3,64 & 3,67 & 3,78 & 20. \\
\hline 18. & $\begin{array}{l}\text { Dokumentáció rendelkezésre } \\
\text { állása }\end{array}$ & 3,63 & 3,42 & 3,92 & 3,89 & 3,78 & 18. \\
\hline 19. & Ergonómia & 3,25 & 3,69 & 3,58 & 3,59 & 3,56 & 19. \\
\hline 20. & A gyártó hírneve & 2,75 & 3,31 & 3,29 & 3,17 & 3,19 & 16. \\
\hline
\end{tabular}

A magyar vállalkozások szempontjából elemezve a kapott eredményeket azt tapasztalhatjuk, hogy átlagosan a használhatóság, a megbízhatóság és a hálózati kapcsolhatóság lehetősége a legfontosabb szempontok a kiválasztás során, míg a gyártó hírneve és az ergonómia a legkevésbé fontos tényezók a bevezetés folyamán. Vállalati méret szerinti összehasonlításban a magyar vállalkozásoknál is megfigyelhetố a mikroszegmens eltérố preferenciája a bevezetési döntésekben. A kipróbálási lehetôséget például sokkal fontosabb tényezónek tartják a többi vállalkozásnál, míg a felhasználók támogatása szempont fontossága elmarad a nagyobb vállalkozások értékelésétôl (6. táblázat).

Összehasonlítva a két ország vállalkozásainak szempontrendszerét megállapítható, hogy a használhatóság és a hálózati kapcsolódás mindkét ország esetében az egyik legfontosabb tényező az információs rendszerek bevezetési döntéseiben, az ergonómia pedig a legkevésbé figyelembe vett szempont a döntés során. Meg- figyelhetố továbbá a mikrovállalkozások a sok esetben elteroó a szempontrendszere a nagyobb méretú vállalkozásoktól, a bevezetési döntések során.

\section{Az alkalmazott információs rendszer}

A vállalkozások által használható információs rendszerek, a tipologizálásuknál leírtak alapján, igen sok változatot mutatnak. A vállalati tevékenység teljes spektrumát felölelik, az egyszerú adatfeldolgozástól kezdve a döntés-elôkészítés támogatásáig. Természetesen a rendszerek használati gyakorisága jelentós eltéréseket mutat a vállalkozási méret alapján vizsgálva. Könnyen belátható, hogy a nagy szervezetek komplex igényeiket a változatos célokat szolgáló információs rendszerek használatával elégíthetik ki. A kisebb vállalkozások esetében az információs rendszerek elérhetôsége és használati lehetôsége is korlátozottabb. A megkérdezett vállalkozások által kitöltött kérdőiv 


\section{Az üzleti információs rendszerek használati megoszlása méretkategóriánként} Horvátországban és Magyarországon

\begin{tabular}{|c|c|c|c|c|c|c|}
\hline Üzleti információs iendszer típusa & Ország & $\begin{array}{c}\text { Mikro- } \\
\text { vállalkozás }\end{array}$ & \begin{tabular}{|c|} 
Kis- \\
vállalkozás
\end{tabular} & \begin{tabular}{|c|} 
Közép- \\
vállalkozás
\end{tabular} & $\begin{array}{c}\text { Nagy- } \\
\text { vállalat }\end{array}$ & Átlag \\
\hline & & $\%$ & $\%$ & $\%$ & $\%$ & $\%$ \\
\hline \multirow{2}{*}{ Tranzakcio-feldolgozo rendszer (TPS) } & Horvátország & 27,27 & 42,86 & 90,48 & 95,65 & 69,74 \\
\hline & Magyarország & 5,00 & 29,63 & 51,85 & 75,00 & 40,43 \\
\hline \multirow{2}{*}{ Irodaautomatizálási rendszer (OAS) } & Horvátország & 18,18 & 54,55 & 90,00 & 91,30 & 69,74 \\
\hline & Magyarország & 5,00 & 22,22 & 44,44 & 65,00 & 34,04 \\
\hline \multirow{2}{*}{ Vállalati eróforrás-tervezó rendszer (ERP) } & Horvátország & 9,09 & 59,09 & 71,43 & 82,61 & 62,34 \\
\hline & Magyarország & 0,00 & 14,81 & 40,74 & 60,00 & 28,72 \\
\hline \multirow{2}{*}{ Beszállítóikapcsolat-kezelố rendszer (SRM) } & Horvátország & 20,00 & 14,29 & 36,84 & 52,38 & 32,39 \\
\hline & Magyarország & 5,00 & 14,81 & 37.04 & 60,00 & 28,72 \\
\hline \multirow{2}{*}{ Ellátásilánc-kezeló rendszer (SCM) } & Horvátország & 27,27 & 10,00 & 33,33 & 40,00 & 27,78 \\
\hline & Magyarország & 5,00 & 11,11 & 25,93 & 40,00 & 20,21 \\
\hline \multirow{2}{*}{ Ügyfélkapcsolat-kezelő rendszer (CRM) } & Horvátország & 10,00 & 31,82 & 60,00 & 71,43 & 47,95 \\
\hline & Magyarország & 5,00 & 14,81 & 44,44 & 50,00 & 28,72 \\
\hline \multirow{2}{*}{ Vezetói információs rendszer (MIS) } & Horvátország & 10,00 & 22,73 & 66,67 & 82,61 & 51,32 \\
\hline & Magyarország & 0,00 & 7,41 & 40,74 & 60,00 & 26,60 \\
\hline \multirow{2}{*}{ Döntéstámogató rendszer (DSS) } & Horvátország & 9,09 & 9,09 & 33,33 & 60,87 & 31,17 \\
\hline & Magyarország & 0,00 & 0,00 & 18,52 & 35,00 & 12,77 \\
\hline \multirow{2}{*}{ Felsôvezetôi információs rendszer (EIS) } & Horvátország & 9,09 & 9,09 & 28,57 & 42,86 & 24,00 \\
\hline & Magyarország & 0,00 & 3,70 & 25,93 & 45,00 & 18,09 \\
\hline \multirow{2}{*}{ Üzletiintelligencia-rendszer (BI) } & Horvátország & 9,09 & 13,64 & 52,63 & 80,95 & 42,47 \\
\hline & Magyarország & 0,00 & 7,41 & 7,41 & 20,00 & 8,51 \\
\hline \multirow{2}{*}{ Tudásalapú és szakértôii rendszerek (KWS, ES) } & Horvátország & 9,09 & 10,00 & 20,00 & 42,86 & 22,22 \\
\hline & Magyarország & 0,00 & 7,41 & 3,70 & 15,00 & 6,38 \\
\hline \multirow{2}{*}{ Térinformatika (GIS) } & Horvátország & 0,00 & 4,76 & 10,00 & 42,86 & 16,44 \\
\hline & Magyarország & 5,00 & 3,70 & 14,81 & 40,00 & 14,89 \\
\hline \multirow{2}{*}{ Intranet } & Horvátország & 27,27 & 40,91 & 90,00 & 91,30 & 67,11 \\
\hline & Magyarország & 15,00 & $18,52 \%$ & 37,04 & 85,00 & 37,23 \\
\hline \multirow{2}{*}{ Magasabb használati arány } & Horvátország & 12 & 11 & 11 & 12 & 13 \\
\hline & Magyarország & 1 & 2 & 2 & 1 & 0 \\
\hline
\end{tabular}

a 13 legjellemzóbb információs rendszer típust tartalmazta. A vállalkozások megjelölhették, azon kívül, hogy milyen információs rendszert használnak aktuálisan, azt is, hogy tervezik-e a kérdoóívben szereplő információs rendszerek valamelyikének bevezetését. Az elemzések alapján a horvát vállalkozások körében átlagosan leggyakrabban használt információs rendszer a TPS, az összes mintában lévô vállalkozás $69,7 \%$-a használ ilyen rendszert. Az eredmény nem meglepó, hiszen a TPS-rendszerek az általános üzleti események feldolgozását segítik, ezért a legtöbb vállalkozás múködését nagymértékben támogatják. Magas arányban használják továbbá az OAS- $(69,7 \%)$, az intranet $(67,1 \%)$ és ERP-rendszereket $(62,3 \%)$. Az átlagosan legkevésbé használt információsrendszer-típusok a vizsgált horvát vállalkozások esetében az EIS- (24\%), a KWS- $(22,2 \%)$ és a térinformatikai rendszerek
$(16,4 \%)$. Természetszerúleg a komplex, speciális funkciókat kielégító információs rendszerek alkalmazását a vállalati méret és tevékenységi terület determinálja. A vállalati méret alapján vizsgálva az alkalmazott rendszertípusokat, a mikrovállalkozások esetében a már említett TPS-rendszerek és SCM-rendszerek használata a leggyakoribb $(27,2 \%)$. A többi információs rendszer használata ebben a méretkategóriában ritka. A kisvállalkozások oldaláról vizsgálva már magasabb arányú használati mutatókat kaptam, a leggyakoribb az OAS- $(54,5 \%)$ és az ERP $(42,8 \%)$ rendszerek használata, TPS-rendszert a kisvállalkozások közel a fele használ $(42,8 \%)$, intranetes hálózatot pedig 57 százalékuk. Középvállalatok esetén a használati arányok tovább emelkednek, esetükben a leggyakrabban használt rendszerek a TPS- $(90,5 \%)$, az OAS- (90\%), az intranet $(90 \%)$ és az ERP- $(71,4 \%)$ rendszerek használata. 
A nagyvállalatok esetében a legmagasabbak a használati arányok, igazolva az információs rendszerek használatának vállalati mérettel való szoros összefüggését. Esetükben a TPS $(95,6 \%)$, az OAS $(91,3 \%)$, az intranet $(91,3 \%)$, az ERP $(82,6 \%)$ és a MIS $(82,6 \%)$ használata a leggyakoribb. Minden információsrendszer-típusra vizsgálva igaz az, hogy a vállalati méret növekedésével az információs rendszerek használatának gyakorisága is emelkedik.

A magyar vállalkozások oldaláról nézve, az átlagosan leggyakrabban alkalmazott rendszer a TPS $(40,4 \%)$, az intranet $(37,2 \%)$ és az OAS (34\%). Ezek megegyeznek a horvát vállalkozások által leginkább alkalmazott információsrendszer-típusokkal. Lényeges különbség azonban, hogy a rendszerek használati arányai alacsonyabbak a magyar vállalkozások esetében. Méret szerinti összehasonlításban a magyar mikrovállalkozások igen alacsony arányban használnak információs rendszert, a leggyakrabban alkalmazott intranetes funkció is csak a magyar mikrovállalkozások 15 százalékában jelenik meg. A kisvállalkozások esetében a leggyakoribb a TPS $(29,6 \%)$, az OAS $(22,2 \%)$ és az intranet $(18,5 \%)$ alkalmazása, ez a TPS- és az OAS-rendszerekben megegyezik a horvát mintával, de arányaiban elmarad attól A magyar középvállalkozásoknál szintén a TPS $(51,8 \%)$ a leggyakoribb, ezt követi az OAS- $(44,4 \%)$ és a CRM$(44,4 \%)$ rendszerek használata. Használati arányaikban itt is elmaradnak a horvát társaiktól. Nagyvállalati szinten vizsgálva az intranet- (85\%), a TPS- (75\%) és az OAS- $(65 \%)$ rendszerek használata a jellemzó, ezt követi az ERP-, MIS- és SRM-rendszerek használata 60 százalékos aránnyal. A magyar vállalkozások esetében is megfigyelhetô, hogy a méretkategória növekedésével, a mikrovállalkozásoktól a nagyvállalatok felé haladva, minden típusú információs rendszer használati aránya emelkedik.

Az országok közötti összehasonlítás alapján a két ország vállalkozásai méretüktôl függóen ugyanazon információsrendszer-típusokat használják, továbbá a kérdőívet kitöltố horvát vállalkozások nagyobb arányban használnak információs rendszereket mindennapi múködésük során, mint a magyar vállalkozások. Az eltérések vállalati méretkategóriától függetlenül minden mérettípusban kimutathatók (7. táblázat).

\section{Összefoglalás}

A globalizáció térnyerése és a kialakulóban lévố globális információs társadalom támasztotta kihívásoknak a vállalkozások csak akkor tudnak megfelelni, ha az információtechnológiát nagymértékben integrálják az üzletmenetbe. Az elvégzett kutatás során lehetôség volt megvizsgálni és összehasonlítani, hogy a horvát és magyar vállalkozások hol tartanak azon az úton, amely biztosíthatja számukra az információs rendszerek alkalmazásával elérhetô elő́nyök minél teljesebb kihasználását. A primer kutatási munka alapját képezô kérdőív értékelésével lehetôségem nyílt a kutatási koncepcióban megfogalmazott feltételezések igazolására. A kutatási eredmények feldolgozása után megállapítható, hogy a feltételezéseim csak részben bizonyultak helytállónak. A felmérésbe bekapcsolódó magyar vállalkozások körében várt magasabb szintú információsrendszerintegráció, a minták feldolgozása és a kutatásban részt vevố horvát vállalkozások eredményeivel történő öszszehasonlító elemzés után nem sikerült alátámasztani. Az elemzés alapján a mintában szerepló horvát vállalkozások átlagosan magasabb arányban használják ki az információs rendszerek lehetôségeit. Múködésük során nagyobb arányban és több feladat kielégítésére alkalmas információs rendszert használnak. Horvátország az európai uniós csatlakozásával, és ezáltal a Digitális Menetrend stratégiai programban való részvételével, várhatóan tovább növeli a vizsgálat eredményei szerint is meglévő előnyét, így a két ország vállalkozásai között kimutatott különbség további növekedése várható. Az összehasonlító elemzés során minden esetben elvégeztem a két ország közötti vizsgálatot a vállalkozási méret szerinti relációban is. Az így nyert információk alapján megállapíthattam, hogy a különbözó országok azonos méretú vállalkozásaira teljesül-e feltételezésem, amely szerint a különbözố országok azonos méretú vállalkozásai hasonló információsrendszer-használati szokásokkal és elvárásokkal rendelkeznek. A feltételezés a mikrovállalkozások kivételével beigazolódott. Az azonos gazdasági és kulturális régióban található országok vállalkozásai alapvetően hasonló környezeti kihívásokkal szembesülnek. Ezekre a kihívásokra pedig az információs rendszerek arányaiban hasonló használatával és a rendszerekkel szemben támasztott hasonló elvárásokkal válaszolnak. Speciális a mikrovállalkozások helyzete, amelyek méretükból és piaci helyzetükból adódóan bizonyos esetekben igen eltérôen viselkednek az országos és az országok közötti összehasonlításban is.

A nemzetközi összehasonlítás kiterjesztésével meghatározhatóak a vállalkozások és a többi gazdasági szereplő fejlesztendố területei. A kutatási tevékenység folytatása, rendszeres idóközönkénti ismétlése pedig a kitúzött célok teljesülésének ellenôrzését, illetve a változó környezeti hatások tendenciáit képes feltárni, ezáltal is támogatva a vállalati és gazdasági élet szereplőinek eredményesebb múködését, hatékonyságuk növelését, információs rendszerekkel kapcsolatos döntéseik objektív megalapozását. 


\section{Lábjegyzet}

${ }^{1}$ A bemutatott kutatómunka a TÁMOP-4.2.1.B-10/2/KONV-20100001 jelú projekt részeként az Európai Unió támogatásával, az Európai Szociális Alap társfinanszírozásával valósul meg.

\section{Felhasznált irodalom}

Bencsik B. (2011): Az üzleti információs rendszerek használati szokásainak elemzése a vállalkozások körében. Szakdolgozat. Miskolc

Bubenkó T. (2011): IT - elốny vagy lételem? A magyar és az olasz kkv-szektor vállalkozásainak üzleti információs rendszerrel való ellátottsága. Szakdolgozat, Miskolc

Burt, E. - Taylor, J.A. (2003): Information and Communication Technologies: Reshaping . Voluntary Organizations? Nonprofit Management and Leadership, Volume 11, Issue 2, p. 131-143.

Csala P. - Csetényi A. - Tarlós B. (2003): Az informatika alapjai. Budapest: ComputerBooks

Cser L. - Németh Z. (2007): Gazdaságinformatikai alapok. Budapest: Aula Kiadó
Dobay P. (1997): Vállalati információmenedzsment. Budapest: Nemzeti Tankönyvkiado

Drótos Gy. - Gast K. - Móricz P. - Vas Gy. (2006): Az információmenedzsment fejlettsége és a versenyképesség. Versenyben a világgal 2004-2006 gazdasági versenyképességünk vállalati nézőpontból c. kutatás. Versenyképesség-kutatások múhelytanulmány-sorozat. 28. sz. múhelytanulmány. Budapest

Erdós F. (2005): A kis- és közepes vállalkozások versenyképességének növelése integrált vállalatirányítási rendszerek által. Gyốr: Széchenyi István Egyetem

Gábor A. és munkatársai (2007): Üzleti informatika. Budapest, Aula Kiadó

Gábor A. (szerk.) (1997): Információmenedzsment. Budapest, Aula Kiad6

Kacsukné Bruckner L. - Kiss T. (2007): Bevezetés az üzleti informatikába. Budapest: Akadémiai Kiadó

Raffai M. (2003): Információrendszerek fejlesztése és menedzselése. Budapest: Novadat Kiadó

Vasas G. (2012): A magyar és horvát vállalkozások üzleti információs rendszerekkel való ellátottságának elemzése. Szakdolgozat. Miskolc 